\title{
Od diskurzívneho konštruovania literárneho realizmu k realistickému interdiskurzívnemu konštruovaniu reality
}

\section{MILAN KENDRA}

DOI: https://doi.org/10.31577/WLS.2021.13.4.11

V slovenskej literárnej vede uplynulých dvoch desatročí bol historiografický výskum podstatnou mierou orientovaný aj na texty a kontexty literárneho realizmu. ${ }^{*}$ Realizoval sa v znamení obratu dotovaného nevyhnutnostou uvolnit (dis)kontinuitu literárneho procesu zo závislosti od spoločenských udalostí a východísk - inovatívne metodologické impulzy boli výzvou odpútat model dejín literatúry od predstavy „lineárneho, teleologicky predurčeného vývinu a pokroku“ (Zajac 2009, 35) a zdôraznit "popri invariantnosti mnohopočetnost’ a diferencovanost' vztahov a väzieb, utvárajúcich jednotlivé literárne diskurzy, konfigurácie a dynamickost̉ ich vztahovania" (36). Pri primeranom zúžení tohto záberu na diskurz literárneho realizmu platí, že funguje ako interferenčný systém a literárne texty označované za realistické vykazujú vysokú mieru heterogenity a synkretizmu. Tento koncept sa v domácom literárnohistorickom a literárnoteoretickom výklade realizmu kryštalizoval dlhšie obdobie, a preto $\mathrm{z}$ množstva publikačných výstupov pripomeňme aspoň zborník Reálna podoba realizmu (2011) so štúdiami, ktoré vymedzujú štrukturálne rámce „hry na realizmus“ (Mikulová 2011, 7), resp. identifikujú konvencie konštruovania realistickej ilúzie či efektu reality.

\section{INTERFERENČNÝ MODEL KONŠTRUOVANIA DISKURZU SLOVENSKÉHO LITERÁRNEHO REALIZMU}

Syntézu uvažovania o literárnom realizme ako o interferenčnom systéme, a teda o diskurze, $\mathrm{v}$ rámci ktorého dochádza $\mathrm{k}$ špecifickým konfiguráciám prvkov rôzneho pôvodu (nielen literárneho, estetického, ale aj kultúrnohistorického, sociálneho), predkladá kolektívna monografia Konfigurácie slovenského realizmu (2016). Udalost’ slovenského literárneho realizmu 19. storočia projektuje ako divergentnú, pluralitnú a procesuálnu a interpretuje ju ako „konfiguráciu viacerých heterogénnych umeleckých, kultúrnych a ideologických diskurzov, v rámci ktorej sa diskurz umeleckého realizmu v dôsledku rôznorodých vztahov pretvára, modifikuje a prispôsobuje“ (Taranenková 2016, 36). V tejto heterogénnej, dynamickej a divergentnej diskurzívnej formácii sa prejavujú markery rôznorodých diskurzov, realizujú sa v nej procesy ich modifikácie a rekontextualizácie, adaptácie a eliminácie. Konfiguračné konštru-

* Štúdia je súčastou riešenia grantových úloh APVV-18-0043 „Slovník diel slovenskej literatúry po roku 1989“. 
ovanie diskurzu slovenského literárneho realizmu $\mathrm{v}$ tejto perspektíve prebieha na podloží teórie otvorených a dynamických, vzájomne presietovaných systémov, ktorá predpokladá realizovanie výmen medzi systémom a jeho okolím (výmeny môžu byt konceptualizované rôzne $\mathrm{v}$ závislosti od povahy systémov). Vo významotvornom systéme, akým je aj literatúra, ide o výmenu informácie. Pre literárnohistorické obdobie v pozícii takéhoto (sub)systému sú relevantné nielen imanentné zmeny, ale aj zmeny podmienené tlakom okolia a zmeny podmienok okolia - pulzačný model literárnych dejín sa preto orientuje na „prieniky funkčných systémov“ (Zajac 1993, 422), zakladá svoje opodstatnenie aj na „priestupnosti hraníc“, „prienikoch jednotlivých sfér životného sveta“ či na „ustavičnom prekračovaní hraníc literárnosti“ (422). Pre tento model je príznačná aktivita mapovania „kízavých, difúznych hraníc, vzájomných prienikov a prelínaní" (Zajac 2006, 20), má záujem o synoptické procesy, v ktorých „vznikajú medzi jednotlivými pohybmi vztahy v rámci spoločného pola, dochádza $\mathrm{k}$ ich prelínaniu, utvárajú sa medzi nimi interferencie, vzájomné dotyky a prieniky“ (Zajac 2009, 34 - 35). Uvedená interferenčná perspektíva je navyše aplikovatelná aj v prípade prechodov od národnej $\mathrm{k}$ stredoeurópskej/európskej literatúre (a spät), v ktorých sa reflektujú „vzájomné dotyky, prelínania a prieniky, poukazuje [sa] na miesta vzájomných korešpondencií a ekvivalencií “ (41). Interferenčná povaha literárneho dejepisectva je zakódovaná v konceptoch polyfunkčnosti, polyfokality, polyperspektívnosti, polychrónnosti a polyteritoriality, cez ktoré sa na literárne texty nazerá nielen ako na súčast' literárneho, ale aj kultúrneho archívu (36).

$\mathrm{Na}$ pozadí literárnovednej reflexie textov slovenskej literatúry druhej polovice 19. storočia je zrejmé, že dispozíciu slovenského realistického diskurzu vytvárajú konfiguračné vztahy. Konštruuje sa v interakciách s príznakmi viacerých literárnych a kultúrnych diskurzov, preto ho možno reflektovat ako osobitnú diskurzívnu konfiguráciu/formáciu. Podla Petra Zajaca sa realistické konfigurácie vytvárajú v rámci troch úrovní (súradnicových systémov) - „vo vztahoch podobnosti a odlišnosti medzi jednotlivými literárnohistorickými diskurzmi a udalostami, v tkanive osobitnej konfigurácie realistického diskurzu a v tkanive osobitných konfigurácií vo vnútri jednotlivých textov realistického diskurzu" $(2016,26)$. Takéto prostredie je mimoriadne vhodné na interdiskurzívne konštruovanie literárneho realizmu a interdisciplinárne/ interdiskurzívne charakteristiky vykazuje aj jeho literárnovedná reflexia, do ktorej boli transplantované viaceré koncepty špeciálnych diskurzov. V kontexte literárnej vedy tak pri analýze literárnohistorických pohybov frekventovane figuruje (pôvodne ako súčast' geologickej terminológie) niekolko metaforických pojmov - „tektonická“, „príkrovová“ stavba či „katastrofická“ situácia ako vypĺňanie sedimentačného priestoru, tzv. geosynklinály (Čepan [1979] 2003, 76 - 77) s eventuálnymi analógiami $\mathrm{v}$ literárnom procese -, prvému zodpovedá kauzálny princíp kontinuity tradície v ustálenom prostredí, druhému presuny komplexov vrstiev v dôsledku silných tangenciálnych tlakov z iných kultúrnych prostredí a tretiemu prevratný, horizontálny i vertikálny pohyb, neorganické a radikálne preskupovanie vzt̉ahov (77). Aj proces „synoptického kartografovania“ dejín národných literatúr vychádza z konceptu synoptickej mapy (s pôvodom $\mathrm{v}$ synoptickej meteorológii), ktorá nezachytáva viditelný svet, jej vrstevnatost' „nie je na prvý pohlad ,viditel’á‘, [...] ale ,mapuje priestor, ktorý 
je ,nad" krajinou, pričom hovorí viac o ne-viditelnom svete“ (Matejovič 2000, 21). Synopsiu ako „dvojdomú, vedecko-umeleckú/meteorologicko-literárnu myšlienkovú paradigmu" reflektuje aj Anna Kobylińska $(2018,114)$, ktorá zasa v metaforickom termíne „spojivové tkanivo“ (prepožičanom z biologických vied) nachádza potenciál uplatnenia v teoretickom a metodologickom opise slovenskej literatúry a kultúry $(114-115)$.

\section{KONCEPT AUTOPOIESIS (OPERATÍVNEJ UZATVORENOSTI)}

\section{SYSTÉME FORMOVANIA DISKURZU LITERÁRNEHO REALIZMU}

V horizonte interdiskurzívneho konštruovania literatúry a zároveň interdiskurzívneho konštruovania reality $\mathrm{v}$ umeleckých textoch recipovaných ako realistické (v literárnohistorickom a poetologickom vymedzení) je potrebné prehodnotit chápanie otvorených systémov a modifikovat uvažovanie o interferenčnej povahe funkčných systémov, o prienikovosti ich semiotických pomedzí a priepustnosti ich hraníc - aj vzhladom na skutočnost', že „umenie/literatúra/realizmus“ je ako špecifický interdiskurz vystavený pôsobeniu výrazových a významových komplexov špeciálnych diskurzov, ktorých komplexita môže pôsobit vo vztahu k literárnemu (sub)systému deštruktívne. V kontexte systémovej teórie Niklasa Luhmanna (1995, 2000, 2013) predstavuje umenie samostatný funkčný systém vznikajúci v spoločenskom prostredí, pričom platí, že takéto sú operatívne uzatvorené a samy seba organizujú. Princíp operatívnej uzatvorenosti pomáha vymedzit hranicu systému (literatúry) ako stabilizáciu diferencií medzi vnútorným (operácie vlastné systému) a vonkajším (prostredím, okolím, ktoré je vždy komplexnejšie ako systém samotný). Konfigurácia diskurzu slovenského literárneho realizmu predstavuje vo vztahu k prostrediu funkčne diferencovaný subsystém literárneho systému tým, že disponuje zásadnou funkčnou diferenciáciou, ktorá pomáha udržiavat kompatibilitu jeho vnútorných procesov a hranicu s bezprostredným diskurzívnym okolím. Túto skutočnost' signalizujú tzv. realistické pohyby operujúce v realistických fikčných svetoch, „pohyb individuálně-psychologický a pohyb sociálně-ideologický" (Fořt 2014, 31) a tiež hierarchizovaný súbor funkcií v metodologickom návrhu realistického fikčného sveta. $\mathrm{V}$ ňom je popri dominantnej estetickej funkcii vyčlenená aj čiastočne nadradená epistemologicko-edukačná funkcia, ktorá $\mathrm{v}$ súčinnosti s realistickou evokačnou funkciou zabezpečuje kognitívnu (poznávaciu) funkciu umeleckého diela. V stratifikácii realistickej evokačnej funkcie (38 - 41) pôsobí sémanticko-pragmatický status realistických fikčných diel ako „fikcií o realite“, a preto ju možno dalej špecifikovat ako funkciu subjektovú, priestorovo-časovú, individuálno-charakterovú, ideologickú, resp. tieto evokácie sú viazané topologicky (historické, geografické, personálne, objektové, epistemologické, kultúrne, jazykové, dokumentové, svedecké a pod.). Literárny realizmus teda možno považovat za sociálny, sebareferenčný, uzavretý, autopoietický literárny subsystém, ktorého funkčná diferenciácia pomáha udržiavat hranicu tohto systému vo vztahu k okoliu a katalyzuje možnosti komunikačných výmen (série reakcií) so systémami existujúcimi v jeho okolí. Kedže realistický diskurz predpokladá silný analytický a interpretačný vztah k historicky konceptualizovanému horizontu sociálnej reality, má zásadné predispozície vytvárat si vnútornú 
komplexitu v komunikáciách so špeciálnymi diskurzmi (filozofia, kognitívne vedy), a preto splňa predpoklady, aby na jeho rozhraní vo vysokej miere prebiehali interdiskurzívne operácie.

Koncept autopoietického, operatívne uzatvoreného systému neznamená, že si nevytvára kontakty s prostredím. Demarkačná línia vymedzujúca hranice systémov je východiskovou diferenciou, ktorá podmieňuje ich komunikáciu prostredníctvom porovnatelných štruktúr (Luhmann 2000, 1) rôznorodých systémov (literárneho/umeleckého, vedeckého, náboženského, politického, ekonomického a pod.) s odlišnými operatívnymi modmi a funkčnou diferenciáciou. Platí, že „systém může vyvíjet svou identitu pouze $\mathrm{v}$ diferenciaci $\mathrm{k}$ prostředí, a tím se stává jeho poměr $\mathrm{k}$ prostředí konstitutivním faktorem jeho vlastní sebetvorby“ (Šubrt 2001, 131). Nejde tu teda o návrat ku konceptu uzatvoreného systému, ale o identifikáciu a špecifikáciu okolností, ktoré dynamiku a otvorenost’ systémov podmieňujú. Funkčne diferencované systémy nie sú schopné ovplyvňovat’ a prestupovat sa priamo. Relácie medzi psychickými systémami (vnímanie a vedomie), sociálnymi systémami (napr. umením) a systémami komunikácie prebiehajú v postupnostiach pozorovaní a inferencií, ktoré umožňujú sledovat referenčné akty, ktorými sa ostatné systémy navonok vymedzujú vo vztahu $\mathrm{k}$ okoliu, a usudzovat o ich vnútorných sebareferenčných operáciách. V súčinnosti s nimi jednotlivé autopoietické systémy modifikujú svoju vnútornú komplexitu pohybmi príznačnými pre vlastný operatívny modus. Systémy teda komunikujú na báze diferencií a v prípade, že niektoré štruktúrne väzby vyhodnotia ako významotvorné (ako informácie), reagujú na ne zmenami svojho systémového usporiadania. Tým, že vnútorné horizonty týchto systémov zostávajú vzájomne nedostupné (Luhman 2000, 48), sa mení aj chápanie samotnej komunikácie - už neznamená „prenos“ informácie, ale tvoria ju procesy selekcie, predstavuje „emergentní jednotky, které uvádí do chodu mechanismy selekcí a výběrů možností vedoucí k výstavbě struktur" (Šubrt 2001, 126). Pre problematiku interdiskurzívneho konštruovania literárneho systému (a interdiskurzívneho konštruovania reality $\mathrm{v}$ textoch literárneho realizmu) je koncept autopoiesis a operatívnej uzatvorenosti systému dôležitý, aby súčasti špeciálnych diskurzov, ich poznanie a skúsenost deštruktívne nezasiahli a nenivelizovali ikonické a zážitkové parametre literárneho pola. Udržiavanie identity, hranice (realistického) literárneho systému diferenciáciou vo vztahu $\mathrm{k}$ prostrediu (sociálnym systémom, systémom vied) má opodstatnenie, pretože okolie poskytuje „vždy více možností, než si systém může přisvojit a zpracovat, je tedy nutně komplexnější než systém sám“ (123). Selektívnymi operáciami redukujúcimi narastajúcu komplexitu okolia sa systém upravuje a udržiava. Ide tu o mieru rešpektovania interdiskurzívnej otvorenosti alebo uzatvorenosti diskurzívnej konfigurácie literárneho realizmu, o rozvíjanie jej funkčnej diferenciácie a vnútornej komplexity aj s ohladom na fakt, že postupy a výrazové prostriedky literárneho realizmu sa $\mathrm{v}$ opisoch skúsenosti, v evokácii ilúzie či dojmu reality inšpirujú nefikčnými formami a žánrami, uplatňujú fikcionalizáciu či imitáciu nefikčného diskurzu, napr. realistický román nie je „ovlivněn filozofií či vědou pouze ideově, nýbrž i metodologicky, terminologicky a stylově“ (Fořt 2014, 19).

V porovnaní s predstavou prienikovosti systémov Luhmannov koncept autopoiesis a funkčnej uzatvorenosti umožňuje na úrovni interdiskurzov sledovat ich komu- 
nikácie v horizonte diferencií a prilahlých kontingencií (neprediktability, neistoty, nestability, nepravdepodobnosti). Tie sú nevyhnutne späté s komunikačnými rezonanciami, $s$ redukciou komplexity v rámci systémov, $s$ ich selektívnymi operáciami, vzájomnými pozorovaniami a interpretáciami. Možno tým vysvetlit aj neobvyklé interdiskurzívne pozície, $\mathrm{v}$ ktorých sa formulácie $\mathrm{s}$ pôvodom $\mathrm{v}$ špeciálnych diskurzoch vyskytujú. $\mathrm{V}$ textoch literárneho realizmu (literárneho podsystému) pri konštruovaní realistických fikčných svetov možno aj tie interdiskurzívne javy, ktoré majú povahu zlomov, ruptúr, ne-viditelných súvislostí a stôp, sledovat $v$ neinterferenciálnych vztahoch, $\mathrm{v}$ ich diskontinuite, nepredvídatelných a nemotivovaných posunoch. V komunikáciách, ktoré prebiehajú prehodnocovaním kompatibility porovnatelných štruktúr, väzieb a korešpondencií, sú to systémy, ktoré rozhodujú o dôležitosti faktorov $\mathrm{z}$ ich okolia, a výber $\mathrm{z}$ aktuálneho horizontu možností si realizujú podla vnútorných dispozícií. Štruktúry formované sebareferenčnými operáciami sú následne (v prípade porovnatelných štruktúr) overované z hladiska konektivity s dianím a stavom štruktúr $\mathrm{v}$ iných systémoch. $\mathrm{V}$ tejto perspektíve sú interdiskurzívne operácie realizované v priestore komutácie, ko-evolúcie systémov, ako proces re-produkcie porovnatel'ných štruktúr $\mathrm{v}$ interných podmienkach jednotlivých systémov. Nejde tu teda o priamy vstup (import) z okolia do poznávacieho systému, ale o reakciu systému v horizonte diferencií, ktoré sú preň príznačné. Pri uvažovaní o interdiskurzívnom potenciáli realizmu je preto potrebné rešpektovat ho ako autopoietický systém s vlastnými mechanizmami utvárania vnútornej komplexity a jej integrácie. Potom aj pre diela považované za realistické platí, že „[e]stetická povaha poznání prostředkovaného uměleckým dílem spočívá teda $\mathrm{v}$ tom, že všechny složky lidského poznávacího postoje, zkušenosti emotivní, intuitivní, imaginativní i racionální, vystupují v uměleckém díle ve specifické jednotě jako nedílný, integrovaný kognitivní celek" (Chvatík 2001, 106).

\section{EXEMPLIFIKÁCIA INTERDISKURZÍVNEHO KONŠTRUOVANIA REALITY V TEXTOCH REALISTICKÉHO DISKURZU}

$\mathrm{Na}$ dvoch prozaických textoch slovenského realizmu druhej polovice 19. storočia sa pokúsime ilustrovat niektoré interdiskurzívne komunikačné výmeny, stimuly a podnety z prostredia, voči ktorému sa dobový literárny systém diferenčne vymedzoval. Pozornost bude venovaná menej viditelným či latentným osciláciám, resp. komutáciám špecifických postupov literárneho tvarovania (systém umeleckého jazyka) a ideovo-estetických systémov, napr. humanitných vied (filozofia, estetika, história) či dobovo prestížneho systému kauzality a logiky tzv. pozitívnej vedy. Reflektované budú rezonancie faktorov z oblastí špeciálnych diskurzov vo vnútorných štruktúrach textov domáceho realistického diskurzu a spôsob, ako heteroreferenčné operácie $\mathrm{v}$ umeleckom texte (odkazujúce na porovnatelné štruktúry $\mathrm{v}$ iných systémoch) prehlbujú významovú výstavbu a konštrukciu realistického sveta.

Črtu „Ostriež“ (Národnie noviny XI, 1880) z cyklu Obrázky z ludu treba na pozadí doterajšieho výskumu diel Svetozára Hurbana Vajanského recipovat’ v konfigurácii literárneho realizmu s dobovým národnoobrodeneckým diskurzom - literatúra ako súčast’ národnoobrodeneckého projektu „sa stáva exponovanou oblastou prezentá- 
cie a realizácie politickej, národnej a kultúrnej identity“ (Taraneková 2016, 38 - 39). Znamená to, že súčasti špeciálnych diskurzov, vo vztahu ku ktorým sa literárny systém dynamicky vymedzuje, vstupujú do komunikačných výmen cez filter ideologickej argumentácie - realistická evokačná funkcia je úzko previazaná s pohybom spoločensko-ideologickým, čo korešponduje s kultúrotvornou silou literárnej aktivity, ktorá mala v krízových momentoch národného života slovenskú spoločnost' „potvrdit a existenčne upevnit', dat jej románovo ontický ráz" (Števček 1989, 5). Vajanského kreatívne pôsobenie na realitu však znamená, že systematický výskum by mal poukázat na prepojenost̉ rozmanitých aspektov jeho pôsobenia v slovenskej literatúre a kultúre (Taranenková-Liptáková 2006, 27). Vzhladom na eklektizmus, protirečivost' a premenlivost Vajanského literárnoestetických názorov, v kontexte „voluntaristického kreativizmu ako globálnej formy sebarealizácie autorského subjektu“ (Čepan $1984,57)$ možno teda očakávat vysokú mieru kontingencií a neprediktabilných posunov v procese interdiskurzívneho konštruovania literárneho sveta.

Črta „Ostriež“ zahŕňa viaceré znaky formujúcej sa Vajanského prozaickej umeleckej koncepcie. Máme na mysli kompozičnú interakciu objektivizujúceho tvarovania témy (plastické modelovanie morfológie krajiny a prírodných scenérií, etnografickú a dokumentárnu evokáciu kontextu reálneho sveta) s úvahovou a hodnotiacou perspektívou rozprávača. Zmyslovo-konkrétnemu modelovaniu čŕt reality však na vrchu Ostriež začína dominovat individuálno-psychologický realistický pohyb, ktorý kontrastuje s farebnými a zvukovými kvalitami z krajinného prostredia. Epicky tvarované detaily, farby a zvuky nedokážu rozprávača „,ytrhnút z dumných myšlienok“ (Vajanský [1880] 1984, 255). Vizuálne a auditívne kvality javov skutočnosti totiž vedú $\mathrm{k}$ úvahám o povahe vysokého národného umenia - to síce organicky vyrastá z (prirodzených) ludových prejavov (motív piesne), avšak dispozíciou, ktorá „by z rozmetaných živlov a chaotického neriadu utvorila súmerné tvorby“ je „slovenskostou presiaknutá fantázia“, „zručná ruka“, „,nnímavé srdce a vysoká mysel“" (256), ktoré ich transformujú do vysoko štylizovanej, arteficiálnej podoby: „Elementov dost’ a dost' na každom kroku pieseň, na každej doline dráma slovenskej lásky, na každom kopci perspektíva krás a harmónií. Zručná ruka, zručná ruka!“ (256) Citovaná epizeuxa pritahuje pozornosṫ recipienta na synekdochu „zručná ruka“ ako prostriedok, ktorým literárny sebareferenčný systém (vo svojom systémovom programe) komunikačne reaguje na štruktúry konštituované $\mathrm{v}$ iných systémoch, špecifických diskurzoch. Má funkciu diferencie, ktorá na jednej strane (v systéme literatúry) je dištinkciou z hladiska umeleckého jazyka prózy, na druhej strane je indikáciou nasmerovanou do okolitého prostredia, ktorou Vajanského text prehlbuje svoju štruktúrnu komplexitu. Ako signál interdiskurzívnej operácie referenčne odkazuje do viacerých oblastí. $\mathrm{V}$ prvom prípade korešponduje s etikou činorodosti Johanna G. Fichteho, s vedomím činorodosti literárnej a duchovnej aktivity, ktorá má spoluvytvárał a menit život jednotlivca i národa. Aj v prípade Vajanského literárnej činnosti ide o motiváciu, ktorou bol étos praktickosti v pozícii intelektuála, vzdelanca, spisovatela, ktorý si aktivisticko-etický aspekt fichteovskej filozofie upravuje podla dobovej potreby (Kusý 1987, 41): „Mnohé národné tarchy odpadli z pliec našich vdaka hubivej vládnej moci, navalme na tie plecia novú tarchu literárnu, nech nezostáva bez ohlasu ten, čo by 
hotový bol seriózne pracovat" (Vajanský [1879] 1979, 154). V období formovania literárnoestetickej koncepcie však bola Vajanského názorová platforma mimoriadne diferencovaná, príležitostne zahŕňala argumenty kantovskej estetiky a zretelnejšie prvky heglovskej estetickej koncepcie (Taranenková-Liptáková 2006, 36). Synekdocha „zručnej ruky“ svojimi metonymickými súvislostami vstupuje do komunikačných výmen aj s dalším okruhom výpovedí o skutočnosti, ktorým je Vajanského koncepcia histórie v kontexte národnej ideológie, resp. jeho historická ideológia (Hollý 2010, 25 - 26). Tá je rozptýlená v spektre statí a v kultúrnej publicistike. V základnej línii je načrtnutá v programovom článku „Slovensko a jeho život literárny“, v ktorom Vajanský konkretizuje podvojnost̉ histórie slovenského národa ako históriu šlachty a históriu masy národa, ktorá „môže byt zachovatelkou národnosti, ale nikdy nie nositelkou velkých národných podani“" ([1881] 2008a, 313). Je to práve duchovná čiastka národa, jeho „vysokí duchovia“ (315), ktorých aktivitou, ako to signalizuje explicit črty „Ostriež", „zaspatá láva slovenského života rozprúdi sa mocne, neodolatel’ne!“ ([1880] 1984, 257). Synekdocha z tejto prózy napokon rezonuje aj v kontexte Vajanským upravenej tainovskej objektívnej a deterministickej umeleckej teórie v rozprave „Nálady a výhlady“. Slovenský národ si síce dokázal zachovat jazyk, jadro, esenciu národnosti, ale „nedal im umeleckej, viditelnej formy“ ([1897] 2008b, 366), a preto je úlohou národne zmýšlajúcej inteligencie, aby „vrátili sa k nemu, aby doňho liali olej povedomia, aby to, čo je on, i povedali, národnému bytu dali formu a výraz" (367). Slovenský národ tu Vajanský chápe pomocou konceptov etnosociety a biosociety, aby v stati „Umenie v živote národov“ formuloval tézu o zrastenosti umenia s národom, a teda národ ako genosocieta je tretia, „najvážnejšia osnova umelca a jeho životného diela" ([1912] 2008c, 433), a preto je potrebné pozorovat" vlastný kraj, národ i lud ako „materiál súci a nutkajúci nás tvorit z vlastného vnútra - len treba umne ruku vystriet“" (442).

Ladislav Nádaši-Jégé nás v druhom prípade zaujíma ako autor umeleckej koncepcie, v ktorej je predstava skutočnosti (členenie, spájanie, hodnotenie jej javov) stotožnená $s$ východiskami prírodovedného determinizmu, $s$ teorémami pozitívnych vied a pozitivistickou kauzalitou. Jeho literárne texty predpokladajú kódy produkujúce špecializované poznanie, a preto reprezentujú ,jeden velmi konkrétny typ sveta - a to svet podriadený výkladu pozitivistických vied (v ktorom platia nimi nastolené vztahy a závislosti), čiže je to svet kultúrny, jazykovo a textovo artikulovaný a sprostredkovaný“ (Horváth 2011, 35). Nádašiho tvorivá metóda však zámerne odkrýva rozpor medzi scientistickou koncepciou človeka a sveta (pozitivizmu, darwinizmu, experimentálneho románu) a zákonitostami výstavby literárneho diela. Jeho rané práce uverejnené časopisecky v časovom rozpätí 1889 - 1897 v Slovenských pohladoch („Výhody spoločenského života“, „Pomsta“) a Národných novinách („Žart“, „Vada“, „Kúra“, „Omyl“, „Nero“) sú prozaickými improvizáciami, v ktorých pozorovaním a experimentovaním predvádza na pozadí pozitivistickej kauzality princíp adaptability postáv v kontextoch výchovy, životných okolností a prostredia. Sú to Nádašiho príspevky k literárnej téme malomesta a spoločenskej zábavy, pri ktorých možno uvažovat' o „demaskovaní pokrytectva malomestskej spoločnosti, jej životného štýlu a mravných princípov" (Hučková 2014, 223). Napriek pozitivistickej ideovo-este- 
tickej doktríne sú pre tieto krátke prózy príznačné „črty autorovho karikatúrno-deformatívneho temperamentu. [...] karikatúrna deformácia a komické prevracanie rozporných čŕt, objavujúcich sa na rozhraniach motívov spoločenskej adaptability a prírodných inštinktov človeka" (Čepan 1984, 279). Podla Oskára Čepana bola pre Nádašiho sprostredkovatelom medzi vedeckým a estetickým stanoviskom sociológia ako veda (259), a preto sa sústredíme na tri okruhy porovnatelných štruktúr a ich komunikačné rezonancie medzi umeleckou koncepciou uvedených Nádašiho próz a sociologickou estetickou metódou Jeana-Mariho Guyaua (estetické náhlady, filozofia, morálka) formulovanej v knihách Les problèmes de lesthètique contemporaine (Problémy súčasnej estetiky, 1885) a L'art au point de vue sociologique (Umenie zo sociologického hladiska, 1889).

V prvom okruhu ide o kritiku naturalizmu ako analytickej a pokusnej metódy v literatúre. V tejto súvislosti sa obvykle pripomína článok o Zolovom románe Peniaze, v ktorom Nádaši kritizoval proces falzifikácie umeleckej evokácie skutočnosti (princípu pravdivosti) doktrínami literárneho naturalizmu: „Každá scéna sama o sebe robí dojem bezpodmienečnej pravdivosti, avšak celok nemožno verit“" ([1891] 1979, 361). Nádaši poukazuje na kompozičný a koncepčný nedostatok naturalistického románu, na úzke kritérium výberu fabulačných udalostí, ktoré v ňom majú reprezentovat fakty prirodzeného života. Rezultátom je, že Zolove práce sú „síce pravdepodobné, ale nie pravdivé. Skladbe, umeleckej zaokrúhlenosti, povedzme efektu, obetuje pravdu“ (361). Nádašiho výhrada korešponduje s argumentáciou, ktorú vzniesol Guyau na margo naturalistického románu, ked' prízvukoval, že naturalisti zjednodušili obraz človeka v umení, zredukovali ho na jedinú vášeň, a teda idealizujú, resp. ide o obrátený idealizmus: „[I]dealizovat znamená izolovat a zveličovat danú tendenciu, sklon, vlastnost', aby prevládala" (Guyau [1889] 1955a, 411). Postupy zjednodušovania, abstrakcie a neobmedzenej generalizácie sú príznačnými postupmi dobového naturalizmu a Zola ako románopisec „svojím tažkým a zložitým fyziologickým aparátom je teda zjednodušovatelom" (419).

V druhom okruhu poukážeme v naznačených súvislostiach na chápanie umeleckej prózy ako výrazu spoločenskosti. Vladimír Petrík $(1956,386)$ uvádza, že v kontexte posudzovania Nádašiho literárnych prvotín v spolku Detvan v druhej polovici 80 . rokov 19. storočia Martin Kukučín ocenil jeho zmysel pre spoločenskú satiru, „ktorá v našich pomeroch nám je velimi potrebná a môže vykonat vel'kú misiu“. Nádaši v prvotinách rozrušil tematické stereotypy a kompozičné schémy dobovej pseudoromantickej, sentimentálno-lúbostnej a sentimentálno-vlasteneckej spoločenskej poviedky a novely a klišé $\mathrm{v}$ literárnom obraze malomestského života degradoval parodovaním a ironickým zosmiešňovaním. Nádašiho umelecká koncepcia satiricko-parodického prehodnocovania malomesta predstavovala novú kvalitu aj vo vztahu k obrodeneckej funkcii tzv. senzačnej/zábavnej beletrie, ktorá mala byṫ idealizujúca, moralizujúca, s výchovným aspektom. Kukuč́nova poznámka vníma Nádašiho komické/satirické stvárnenie malomestského sveta ako vítanú možnost diferenciácie spoločenského vedomia, spoločenskej sebareflexie pomocou literárneho tvaru. V tejto línii Nádašiho krátka próza rezonuje s chápaním umenia ako spoločenského javu. Guyau považoval umenie za extenziu spoločnosti na všetky bytosti prírody, umelecká emócia je 
emóciou spoločenskou, individuálny život zlučuje so širším a univerzálnym životom: „Najvyšším cielom umenia je vzbudit estetickú emóciu spoločenskej povahy [...]“ ([1889] 1955b, 245). Umelecký génius/tvorivý duch má menit mravy a myšlienky, smerovat $k$ tvorbe nových alebo ku zmene tu už jestvujúcich spoločností (273).

$\mathrm{V}$ tretom okruhu sa zdôrazňuje prekonanie jednostranného fyziologického determinizmu princípom mravnosti. Podla Jána Števčeka $(1959,270)$ mladý Nádaši s myšlienkou fyziologického determinizmu (termín J.-M. Guyaua) do určitej miery súhlasí - signalizuje to autorovo pozorovanie a experimentovanie s charaktermi postáv, ktoré vo svete malomesta založenom na princípoch mechanického materializmu zákonite mravne zlyhávajú. Napriek postupom objektívneho literárneho skúmania je svet Nádašiho prvotín aj sférou intervencie autorského subjektu v zjavnej komickej postojovej modalite na horizonte epického obrazu. Až na tejto úrovni nadobúdajú deformované charaktery z malomestského prostredia skutočnú výrazovú hodnotu a v nej identifikujeme tretiu podstatnú korešpondenciu Nádašiho umeleckej koncepcie s estetikou života Guyaua. Podla nej je dôležité „nájst', ako a kedy prestáva byt ošklivé ošklivým, čiže v akom zmysle má právo na našu sympatiu“ ([1889] 1955a, 417). Guyauova sociologická estetika totiž vyžaduje, aby sa v umeleckom obraze popri fyziologickom determinizme rešpektovala aj rozumová či mravná reakcia, autorský subjekt „mal by uviest’ do činnosti takzvané „idey-sily“ (idées-forces), ktoré nevylučujú determinizmus, ale ho dovršujú, robia ho ohybným, a tým, že ho zbližujú so slobodou, pripúštajú progresívnu realizáciu mravného a sociálneho ideálu“ (423). Nádaši sa v uvedených súvislostiach už zásadne vzdialil od teoretických princípov naturalizmu - do východiskového fyziologického determinizmu v chápaní postáv vkladá princíp racionality, spoločenskej a morálnej adaptability. $\mathrm{V}$ tejto rovine svoje deficitné postavy komicky vidí a prehodnocuje a až v nej sú Nádašiho pudové a egoistické indivíduá spoločensky a esteticky akceptovatelné, teda sympatické v zmysle Guyauovej estetiky - v synergii citov, ktoré vzbudzujú, a myšlienok, ktoré vyvolávajú, sú zdrojom estetickej a mravnej emócie.

\section{ZÁVER}

Prezentovaná perspektíva interdiskurzívneho konštruovania literatúry predpokladá v otázke realistickej reprezentácie prechod od reprezentatívnej ku konštruktivistickej epistemológii. Klúčové sú pre ňu koncepty autopoiesis, operatívnej uzatvorenosti systému, funkčnej diferenciácie udržiavajúcej jeho pohyblivú hranicu a horizont komunikácie prostredníctvom porovnatelných štruktúr rôznorodých systémov. Vzhladom na to, že podla Luhmanna je prostredie vždy komplexnejšie ako konkrétny systém, do centra záujmu sa dostáva problematika konštruovania koherencie realistického fikčného sveta, otázky kontingencie, redukcie komplexity v komunikačných vztahoch systémov a proces selekcie, ktorý sa ako organizujúci/ usporadúvajúci vektor realizuje v koncipovaní realistického literárneho diela. Realistické fikčné svety sú tzv. malé svety (Lubomír Doležel, Umberto Eco) a neúplnost̉ ako ich špecifická dispozícia predpokladá další výskum aj v horizonte interdiskurzívneho konštruovania literatúry. 


\section{LITERATÚRA}

Čepan, Oskár. [1979] 2003. „Vztahy v literárnom vývine.“ In Literárnoteoretické state, ed. Tomáš Horváth, 76 - 80. Bratislava: Veda, vydavatel'stvo SAV.

Čepan, Oskár. 1984. Stimuly realizmu. Bratislava: Tatran.

Fořt, Bohumil. 2014. Fikční světy české realistické prózy. Praha: Akropolis.

Guyau, Jean Marie. [1889] 1955a. „Naturalizmus v románe.“ In Umenie ako výraz života, ed. a prel. Michal Bartko, 409 - 426. Bratislava: Slovenský spisovatel.

Guyau, Jean Marie. [1889] 1955b. „Spoločenská solidarita ako princíp najzložitejšej estetickej emócie a umeleckej tvorby." In Umenie ako výraz života, ed. a prel. Michal Bartko, 221 - 379. Bratislava: Slovenský spisovatel.

Hollý, Karol. 2010. „The Negation of Event History and Historical Optimism: The Historical Ideology of Svetozár Hurban Vajanský (1881 - 1897).“ Historický časopis 58, Supplement: 23 - 52. Dostupné na: http://www.historickycasopis.sk/pdf/HCsupplement2010.pdf [cit 21. 5. 2021].

Horváth, Tomáš. 2011. „Realistická reprezentácia z perspektívy štrukturalizmu a postštrukturalizmu.“ In Reálna podoba realizmu, eds. Marcela Mikulová - Ivana Taranenková, 23 - 48. Bratislava: Ústav slovenskej literatúry SAV.

Hučková, Dana. 2014. „Téma plesu a bálu v slovenskej literatúre.“ In Kontexty slovenskej moderny, Dana Hučková, 218 - 238. Bratislava: Kalligram - Ústav slovenskej literatúry SAV.

Chvatík, Květoslav. 2001. Strukturální estetika. Brno: Host.

Kobylińska, Anna. 2018. „Spojivové tkanivo: O výskume neviditelných kultúrnych spojov a osohu zo zmeny rámca." In Minulost', súčasnost’ a perspektívy literárnovednej slovakistiky, ed. Radoslav Passia, 110 - 117. Bratislava: Platforma pre literatúru a výskum.

Kusý, Ivan. 1987. Mladý Vajanský (1847 - 1883). Bratislava: Tatran.

Luhmann, Niklas. 1995. Social Systems. Prel. John Bednarz, Jr. - Dirk Baecker. Stanford, CA: Stanford University Press.

Luhmann, Niklas. 2000. Art as a Social System. Prel. Eva M. Knodt. Stanford, CA: Stanford University Press.

Luhmann, Niklas. 2013. Introduction to Systems Theory. Prel. Peter Gilgen. Cambridge: Polity.

Matejovič, Pavel. 2000. Synoptici. Bratislava: Kalligram.

Mikulová, Marcela. 2011. „Na úvod.“ In Reálna podoba realizmu, eds. Marcela Mikulová - Ivana Taranenková, 7 - 9. Bratislava: Ústav slovenskej literatúry SAV.

Nádaši, Ladislav. [1891] 1979. „Peniaze.“ In Slovenská literárna kritika 2, ed. Ivan Kusý, 360 - 365. Bratislava: Slovenský spisovatel.

Petrík, Vladimír. 1956. „Literárne prvotiny Jégého.“ Slovenská literatúra 3, 4: 381 - 405.

Števček, Ján. 1959. „Jégé ako kritik poprevratovej literatúry.“ In Jégé $v$ kritike a spomienkach, eds. Alexander Matuška - Vladimír Petrík, 266 - 281. Bratislava: SVKL.

Števček, Ján. 1989. Dejiny slovenského románu. Bratislava: Tatran.

Šubrt, Jiří. 2001. „Systémová teorie Niklase Luhmanna.“ In Postavy a problémy soudobé teoretické sociologie, Jiří Šubrt, 119 - 134. Praha: ISV nakladatelství.

Taranenková-Liptáková, Ivana. 2006. „Sformovanie koncepcie: 1879 - 1881. (K literárnoestetickým názorom Svetozára Hurbana Vajanského).“ Slovenská literatúra 53, 1: 24 - 48.

Taranenková, Ivana. 2016. „Konfigurácie slovenského literárneho realizmu.“ In Konfigurácie slovenského realizmu, ed. Alena Němcová, 27 - 71. Brno: Host.

Vajanský, Svetozár Hurban. [1879] 1979. „Literárna činnoste.“ In Slovenská literárna kritika 2, ed. Ivan Kusý, 154. Bratislava: Slovenský spisovatel.

Vajanský, Svetozár Hurban. [1880] 1984. „Ostriež.“ In Kandidát. Novely I., ed. Ivan Kusý, 252 - 257. Bratislava: Tatran.

Vajanský, Svetozár Hurban. [1881] 2008a. „Slovensko a jeho život literárny.“ In Koreň a výhonky. Články, ed. Ivana Taranenková, 312 - 316. Bratislava: Kalligram - Ústav slovenskej literatúry SAV.

Vajanský, Svetozár Hurban [1897] 2008b. „Nálady a výhlady.“ In Koreň a výhonky. Články, ed. Ivana Taranenková, 363 - 399. Bratislava: Kalligram - Ústav slovenskej literatúry SAV.

Vajanský, Svetozár Hurban [1912] 2008c. „Umenie v živote národov.“ In Koreň a výhonky. Články, ed. Ivana Taranenková, 432 - 442. Bratislava: Kalligram - Ústav slovenskej literatúry SAV. 
Zajac, Peter. 1993. „Existuje čosi ako pulzačné dejiny literatúry?“ Slovenská literatúra 40, 6: 417 - 425.

Zajac, Peter. 2006. „Literárne dejepisectvo ako synoptická mapa.“ In Mezi texty a metodami: Národni a univerzální v české literatuře 19. století, eds. Dalibor Tureček - Zuzana Urválková, 13 - 22. Olomouc: Periplum.

Zajac, Peter. 2009. „Národná a stredoeurópska literatúra ako súčast’ stredoeurópskej kultúrnej pamäti.“ In Národní literatura a komparatistika, ed. Dalibor Tureček, 33 - 47. Brno: Host.

Zajac, Peter. 2016. „Realizmus - reprezentácia - referencialita.“ In Konfigurácie slovenského realizmu, ed. Alena Němcová, 17 - 26. Brno: Host.

\section{From the discursive construction of literary realism to the realist interdiscursive construction of reality}

Slovak literary realism. Social system(s). Interdiscursive communication. Autopoiesis. Functional differentiation. Comparable structures.

This study examines the internal complexity of Slovak literary realist discourse, which is explained in Slovak studies as the result of diverse relations to the heterogeneous artistic, cultural and ideological discourses of the last third of the 19th century. However, since realistic fiction forms a subsystem of art as a social system (Niklas Luhmann), attention is focused on communications with other social systems and corresponding stimuli, and on the specific (self-referential) literary operations (with their inevitable contingency) involved in the construction of a view of reality. In order to illustrate these communicative exchanges, the final section uses two short interpretations to give examples of different modes of the (literary-) realist interdiscursive construction of reality - voluntaristic (in the fiction of Svetozár Hurban Vajanský) and deterministic (in the context of the short stories of Ladislav Nádaši).

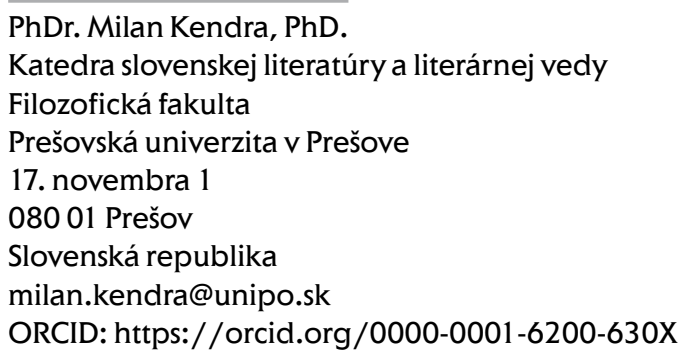

